\title{
Earthworms and Plant Residues Modify Nematodes in Tropical Cropping Soils (Madagascar): A Mesocosm Experiment
}

\author{
Cécile Villenave, ${ }^{1}$ Bodo Rabary, ${ }^{2}$ Emilie Kichenin, ${ }^{1}$ Djibril Djigal, ${ }^{3}$ and Eric Blanchart ${ }^{1}$ \\ ${ }^{1}$ Institut de Recherche pour le Développement (IRD), UMR 210 EcoひSols (INRA, IRD, SupAgro), 2 place Viala, \\ 34060 Montpellier cedex 1, France \\ ${ }^{2}$ Centre National de Recherche Appliquée au Développement Rural (FOFIFA), URP SCRID, BP 230, Antsirabe 110, Madagascar \\ ${ }^{3}$ Institut de Recherche pour le Développement (IRD), UMR 210 EcoひSols (INRA, IRD, SupAgro), LEMSAT (IRD, ISRA), \\ centre de Bel-air, BP 1386 Dakar, Senegal
}

Correspondence should be addressed to Cécile Villenave, cecile.villenave@ird.fr

Received 17 July 2009; Accepted 4 December 2009

Academic Editor: Natchimuthu Karmegam

Copyright ( $) 2010$ Cécile Villenave et al. This is an open access article distributed under the Creative Commons Attribution License, which permits unrestricted use, distribution, and reproduction in any medium, provided the original work is properly cited.

\begin{abstract}
Free-living nematodes present several characteristics that have led to their use as bioindicators of soil quality. Analyzing the structure of nematofauna is a pertinent way to understand soil biological processes. Earthworms play an important role in soil biological functioning and organic matter dynamics. Their effects on soil nematofauna have seldom been studied. We studied the effect of the tropical endogeic earthworm, Pontoscolex corethrurus, on nematode community structure in a 5-month field mesocosm experiment conducted in Madagascar. Ten different treatments with or without earthworms and with or without organic residues (rice, soybean) were compared. Organic residues were applied on the soil surface or mixed with the soil. The abundance of nematodes (bacterial and fungal feeders) was higher in presence of P. corethrurus than in their absence. The type of plant residues as well as their localisation had significant effects on the abundance and composition of soil nematodes. The analysis of nematode community structure showed that earthworm activity led to an overall activation of the microbial compartment without specific stimulation of the bacterial or fungal compartment.
\end{abstract}

\section{Introduction}

Soil organisms play a leading role in decomposition and mineralization of organic matter $(\mathrm{OM})$ [1]. They are involved in processes that affect carbon (C) sequestration as well as in the modification of soil physical structure and chemical properties. They also interact with other soil fauna and these interactions result in complex food webs [2]. Nematodes are small organisms (ca. $1 \mathrm{~mm}$ long at the adult stage) abundant in soil (several million $\mathrm{m}^{-2}$ soil), they present a high species diversity (about 11,000 species have already been described). Nematodes live in the film of water between soil particles and present various feeding behaviours. During the last twenty years, many studies have been conducted on these microfaunal organisms because they can be an efficient tool to assess soil quality and soil biological functioning [2-4]. Because they are present at different levels of the soil food web and present variable tolerance toward stress, nematofauna provide information about OM decomposition pathways and soil pollution status [3, 5-7]. Nematodes interact with other soil organisms including earthworms, which also play an important role in soil biological functioning and OM dynamics $[8,9]$. Until now, studies on interactions between nematodes and earthworms have focused on the contribution of earthworm burrowing and casting activity to nematofauna abundance, composition, and activity [10-14]. These studies were mainly conducted in temperate regions or under specific conditions such as vermicomposting. Results show that interactions between nematodes and earthworms are site and species specific.

In Madagascar, like in other tropical countries, alternative cropping systems are being developed in order to decrease soil erosion and environmental impacts and to 
increase crop productivity or sustainability. No-tillage systems with living or dead (mulch) cover plants have beneficial effects both on environment and crop biomass [15]. In Madagascar, it has been shown that these cropping systems increase the carbon sequestration in soil and decrease soil erosion [15]. Moreover, they increase the density, activity, and diversity of soil fauna and especially earthworms and soil microorganisms [16].

This study was part of a larger project aimed at determining the consequences of earthworm activity for soil aggregation, OM dynamics, and soil biological activity in no-tillage systems in Madagascar [16]. In the present experiment, we focused on the interaction between the tropical endogeic peregrine earthworm P. corethrurus, and soil nematofauna. This earthworm was chosen to be inoculated in the experiment because it was dominant in the study area, feeding and living within the soil although. It is an invasive earthworm, originated from South America.

The abundance and diversity of soil organisms, including nematodes, depend on cropping practices [17]. Indeed, OM amendments like manure generally have a positive effect on microbial biomass and consequently on nematode density $[18,19]$. The quality of the organic resource applied (particularly the carbon to nitrogen ratio $(\mathrm{C} / \mathrm{N})$, lignin, phenolic compounds, and cellulose content) influences the trophic structure of the nematofauna [3]. OM incorporation by tillage can also lead to modifications in the nematode density $[20,21]$.

In this study, we tested the interaction between earthworms and nematofauna under applications of different organic matter (rice residues or soybean residues) brought as mulch or buried in the soil.

\section{Materials and Methods}

2.1. Study Site. The study was conducted in Madagascar in the region of Antsirabe $\left(19^{\circ} 52 \mathrm{~S} ; 47^{\circ} 04 \mathrm{E}\right)$ at an altitude of $1500 \mathrm{~m}$ above sea level. Mean annual temperature is $16^{\circ} \mathrm{C}$ and mean annual rainfall $1300 \mathrm{~mm}$. The climate is subtropical humid with hot and humid summers (Oct-Apr) and cold and dry winters (May-Sep). The soil at the sampling site is highly desaturated red ferrallitic (andic dystrustept), with $62 \%$ clay mainly as 1:1 minerals, but presents andic characteristics. In the upper $10 \mathrm{~cm}$ of soil, carbon content was $45.6 \mathrm{~g} \mathrm{~kg}^{-1}$ dry soil, bulk density was $0.76 \mathrm{~g} \mathrm{~cm}^{-3}, \mathrm{pH}_{\mathrm{H}_{2} \mathrm{O}}$ was 5.7 , the $\mathrm{C} / \mathrm{N}$ ratio was 14.8 , and exchangeable cation capacity was $17.3 \mathrm{cmol} \mathrm{kg}^{-1}$ dry soil [15].

The experiment was conducted in field mesocosms on a $100 \mathrm{~m}^{2}$ plot and lasted 5 months (from January 2005 to June 2005, during the wet season) (see [16] for more details). Fifty plastic buckets $(20 \mathrm{~cm}$ deep) with a diameter of $25 \mathrm{~cm}$ were filled with $8 \mathrm{~kg}$ of soil previously sieved at $2 \mathrm{~mm}$ and homogenised, and were then introduced into the soil so that surface level was similar inside and outside the buckets. Before the buckets were filled with soil, their bottoms were drilled ( 8 holes $1 \mathrm{~cm}$ diameter) and covered with a mosquito net so that water could flow but earthworms could not escape.
2.2. Experimental Design. Ten different treatments were tested: five treatments inoculated with earthworms and five without earthworms. Among the five treatments (with or without earthworms), two received soybean residues, two others rice residues, and one did not receive any residue. When residues were applied, they were placed either on the soil surface or buried. Each treatment was replicated five times, which led to a total of fifty mesocosms in the field experiment. In each bucket with earthworms (E+), six adult or subadult earthworms of the species Pontoscolex corethrurus Müller 1856 (Glossoscoloscidae), sampled near the study site, were inoculated in January 2005. This endogeic geophagous earthworm is a tropical peregrine earthworm [22] abundant in the study area, feeding and living in the soil. Soybean (Glycine max L.) and rice (Oryza sativa L.) residues were added at the same amounts as those measured in cropped fields in local no-tillage systems, that is, $293 \mathrm{~g} \mathrm{~m}^{-2}$ (18.3 $\mathrm{g}$ per bucket) for soybean residues and $365 \mathrm{~g} \mathrm{~m}^{-2}$ (14.6 g per bucket) for rice residues. Soybean residues were mostly composed of woody twigs with a $\mathrm{C} / \mathrm{N}$ ranging between 16 and 23 while rice residues were mainly composed of straw with a $\mathrm{C} / \mathrm{N}$ ranging between 45 and $64[23,24]$. Residues were cut into $2-3 \mathrm{~cm}$ long pieces. Mesocosms were randomly located in the experimental plot. Buckets were watered during the experiment by natural rainfalls.

2.3. Analysis. After 5 months in the field, mesocosms were removed, and their content was separated into a $0-10$ and a $10-20 \mathrm{~cm}$ soil layer. The soil was roughly disaggregated to check that earthworms were still alive. The earthworms were all alive, and since they were mostly present in the $10-20 \mathrm{~cm}$ layer, all analyses were performed in this layer.

Nematodes were extracted from an average of $93 \mathrm{~g}$ of humidified, and homogenized soil (min. $90 \mathrm{~g}$, max. $95 \mathrm{~g}$ ) using the Cobb method. It consists of mixing the soil with a large volume of water allowing a brief time for heavy particles to settle, and then pouring the mixture through several sieves of a mesh size from $500 \mu \mathrm{m}$ to $50 \mu \mathrm{m}$ to retain large debris or nematodes; the second step is used to further clean up the sample ( 48 hours on a $40 \mu \mathrm{m}$ sieve) [25]. Nematodes were counted under a binocular microscope and fixed at $65^{\circ} \mathrm{C}$ with $4 \%$ formalin and subsequently mounted for mass-slide identification $(5 \mathrm{~cm} \times 7.5 \mathrm{~cm}$ slides). An average of 175 nematodes was identified on each slide. Nematodes were identified to family or genus level and assigned to seven trophic groups according to Yeates et al. [26]: bacterial-feeders, fungal-feeders, entomopathogenics, plant-feeders, root hair-feeders, omnivores, and predators. Microbivorous nematode taxa were also allocated to c-p groups following T. Bongers and $\mathrm{H}$. Bongers [5]. Colonizers (c) and persisters (p) are the two extremes on a scale from 1 to 5 , respectively. The c-p value takes into account nematode ecological characteristics, that is, their demography and their life-history strategies [5].

2.4. Statistical Analysis. Differences in taxa and trophic group densities were assessed by ANOVA (Xlstat 2006 Addinsoft) after $\log (n+1)$ transformation of the data. 
A two-way ANOVA was first performed on the 50 samples to test the effects of the addition of earthworms and residues. The 10 samples that did not receive any residues were excluded before performing a three-way ANOVA to test not only the effects of the addition of earthworms and the quality of the residue applied, but also the effect of the location of the residues. A nonparametric multidimensional scaling analysis (MDS) was performed using Primer software (PRIMER-E ltd) to compare the structure of the nematofauna between treatments. Statistical significant differences in community composition between treatments were assessed by analysis of similarities: ANOSIM (which uses permutation/randomisation methods on the similarity matrix).

\section{Results}

In our experiment, 31 nematode taxa were identified. Bacterial-feeders represented $74.9 \%$ of total nematofauna including 12 taxa (Table 1). Fungal-feeders (5 taxa) represented $13.7 \%$ of nematode abundance. An entomopathogenic nematode (Steinernema) was present in some samples and represented $0.3 \%$ of the total density. Plant-feeders represented $6.1 \%$ of total density; 9 genera were identifed (Pratylenchus, Paratylenchus, Aorolaimus, Rotylenchus, Helicotylenchus, Tylenchorhynchus, Meloidogyne, Paratrichodorus, Xiphinema). Root hair-feeders (only members of the Tylenchidae family) represented $3.9 \%$ of the total nematode abundance, whereas omnivores and predators (mainly diverse Dorylaimoidea, Aporcellaimellus, Discolaimus) together represented $1.2 \%$. The ANOVA results on abundance of the different taxa are summarized in Table 1. There was only one statistically significant interaction in the 2-way ANOVA between earthworm and addition of residues; there were more interactions in the 3-way ANOVA between the three factors (earthworm, addition of residues, location of residues) (Table 1).

3.1. Effect of Earthworms on the Density of the Different Nematode Taxa. Total nematode density was significantly higher in the treatments with $P$. corethrurus than in the non-inoculated treatments (Table 1). The density of fungal-feeders was significantly higher in the presence of earthworms. Three nematode taxa were significantly more abundant in inoculated treatments: two bacterial-feeders, Acrobeloides and Prismatolaimidae, and one fungal-feeder, Aphelenchus. For the fungal-feeders, all taxa showed an increasing trend in the presence of earthworms (statistically significant only for Aphelenchus whereas, for bacterial feeders none of the taxa other than Acrobeloides and Prismatolaimidae showed any sign of response). None of the taxa were significantly reduced in numbers due to the presence of the earthworms.

3.2. Effect of Residue Addition on the Density of the Different Nematode Taxa. The addition of residues did not lead to any statistically significant differences between the three treatments (soybean, rice, or no residues) with regard to total nematode density (Table 1), but led to significant differences for the fungal-feeders, which were more abundant in the treatments with residues, whatever the residue quality, than in the treatments without residues. Among the bacterial-feeders, one group (Panagrolaimidae) was more abundant in presence of soybean residues than in absence of residues, whereas several groups (Rhabditidae, Alaimus and Amphidelus) were more abundant when rice residues were added. The abundances of Acrobeles and Cervidellus were reduced due to rice and soybean residues, respectively. Among the fungal-feeders, Aphelenchus density was significantly higher with soybean residues, whereas Ditylenchus density was higher with rice and soybean residues.

Nematode density was significantly higher in the mesocosms with buried residues than with mulched ones (Table 1). Moreover, bacterial-feeders density was significantly higher in the buried residue treatments with significant increases in Rhabditidae, Acrobeloides, Plectidae, Rhabdolaimus, and Amphidelus without any interactions, whereas density of Panagrolaimidae, Prismatolaimidae, and Rhabdolaimus was increased with an interaction between earthworms and localization and Cervidellus, Prismatolaimidae, and Alaimidae with an interaction between residues and localization.

A fungal-feeder group, Tylencholaimoidea, was significantly more abundant in the treatments with buried residues than with mulched ones with no interaction with the others treatments (earthworms and residue), whereas Ditylenchus showed a significant effect of localisation of residues but also an interaction between residue and localization. Entomopathogenics and root hair-feeders were also significantly more abundant in the treatments with buried residues (with no interaction).

3.3. Effect of Addition of Earthworms and Residue on the Structure of the Nematofauna. There was no significant difference in the structure of the nematofauna (abundance of the 31 taxa) between treatments with earthworms and treatments without earthworms (similarity analysis: ANOSIM, $P<.15)$. In contrast, there was a significant difference in nematofauna structure between treatments with rice residues and treatments with soybean residues (ANOSIM, $P<.05$ ) (Figure 1). The outlier is a replicate of the treatment with earthworm, with rice residue addition, mulched residue where an unexplained proliferation of Aphelenchoididae occurred.

There was no significant difference in the structure of the nematofauna between treatments without residues and the two treatments with residues (soybean or rice) (ANOSIM, $P>$.05). Moreover, mixing the residues with soil led to a significantly different structure of the community than that measured in treatments without residues or with residues placed on the soil surface (ANOSIM, $P<.05$ ).

\section{Discussion}

Previous research showed that by grazing and ingestion of nematodes, earthworms could directly affect nematode community structure leading to a decrease in nematode 


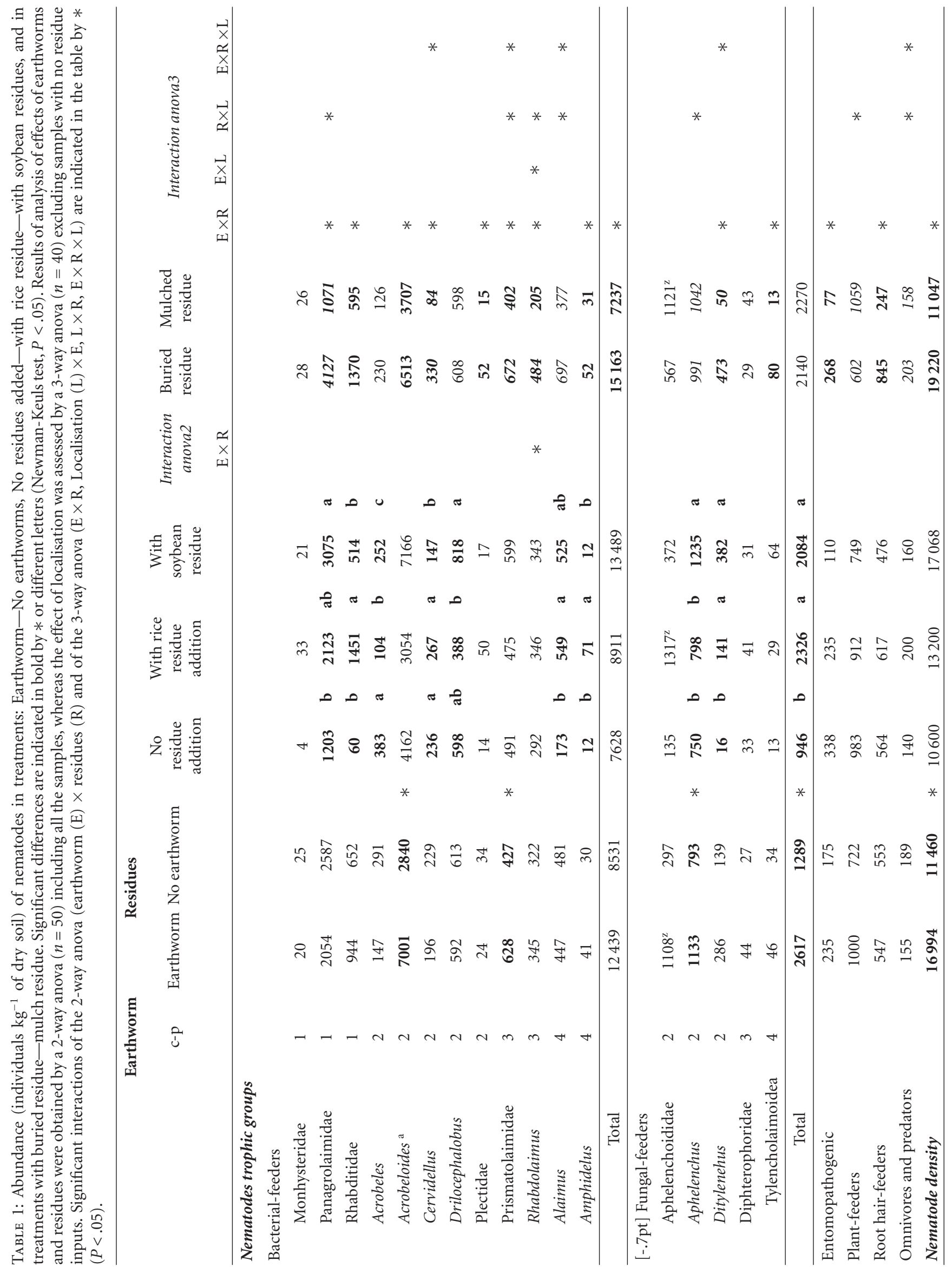




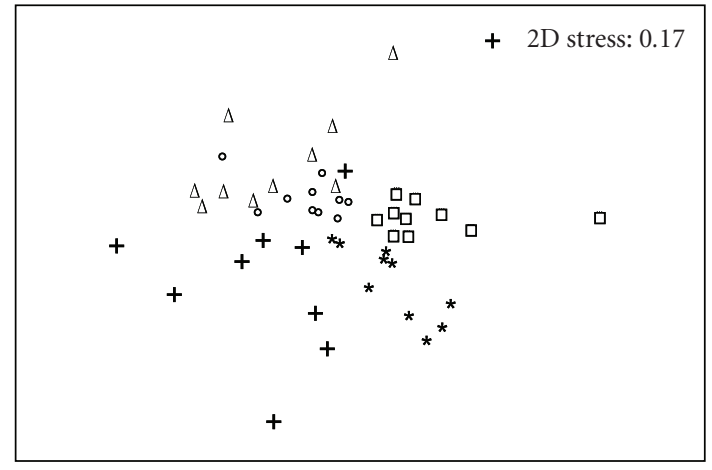

\footnotetext{
- No organic matter input

$\triangle$ Mulched soybean residues

口 Soybean residues mixed with the soil

+ Mulched rice residues

* Rice residues mixed with the soil
}

Figure 1: Multidimensional scaling analysis (MDS) of nematofauna structure for the different organic matter treatments $(n=10$ in each category).

density [13, 27]. Contrary to these results, we found that nematode density was significantly higher in the treatments inoculated with earthworms. These differences may be due to earthworm ecology. Indeed, earthworms modify soil ecosystem properties by casting activity [28] and may thus have an indirect effect on soil microorganisms. Earthworms increase soil OM mineralization by fragmentation but also by the activation of microorganisms during passage through the gut as they secrete intestinal mucus that stimulates microbial activity [29]. This may lead to a priming effect allowing digestion of more complex compounds. The products of this digestion are excreted into casts which are enriched in partially digested OM and in mineral nitrogen [30]. These casts represent a directly available food resource for microorganisms that develop on them. The dominant group of bacterial-feeders, Acrobeloides, was significantly more abundant in the presence of $P$. corethrurus. Moreover, fungal-feeders (and specially Aphelenchus) were more abundant in the treatments inoculated with earthworms. These results indicate that earthworm activity stimulated the microbial community resulting in an increase in the density of microbivorous nematodes. Hyvönen et al. [12] suggested that the reduction of nematode density that occurred in their experiment in presence of earthworms was due to ingestion by earthworms and death during the digestive transit; however, most bacterialfeeding nematode taxa were unaffected by the presence of earthworms (Acrobeloides, Alaimus, Plectidae) in their study.

It was especially fungal feeders that responded positively to the presence of earthworms. As there was no interaction with the residue type, this increase must be mainly controlled by the activity of earthworms themselves (modification of physical and chemical properties). But this interesting issue would need further development to be better understood.
The predominant nematodes in this experiment (Acrobeloides, Panagrolaimidae, Aphelenchus and Aphelenchoididae) are characterized as opportunistic nematodes with high colonisation and reproduction capacities. These nematodes are $\mathrm{r}$-strategists and respond rapidly to a disturbance. They have a c-p value equal to 1 or 2 . Soil sieving, manual homogenization, and soil storage before the experiment led to a simplification of the nematofauna present in the mesocosms compared to a natural ecosystem as the weakest (most fragile) taxa probably died during preparation of the mesocosms. In natural conditions, earthworm activity may also influence these "fragile taxa". Some nematodes with c-p 3 and 4 also responded positively to the buried residues.

Incorporation of OM generally leads to an increase in microbial biomass [31]. Our results showed that buried residues treatment had a positive effect on total nematode density, mainly through an increase in the density of bacterial-feeders. This result could be explained by the improved availability of buried residues for microorganisms compared to mulched residues. The increase in the abundance of bacterial-feeder nematodes (mainly c-p 1 and c-p 2) reflects an increased microbial growth [32] and maybe also an increased microbial biomass [33]. Thus, when residues are buried, microorganism activity may increase and the predominant nematodes might be r-strategists. Our results, obtained under tropical conditions, are consistent with previous studies conducted in temperate regions $[21,34,35]$.

In this experiment, nematode structure differed according to the two types of residues; this difference was not linked to a difference in abundance of the different trophic group but rather to differences in the composition of the bacterial-feeding community. The proportion of bacterialfeeding nematode taxa was very different from one treatment to another, suggesting that the microbial community that degraded these residues differed depending on the quality of the residues applied. We found a significant increase in some bacterial-feeders in the rice residue treatments, including Rhabditidae, an opportunistic c-p 1 nematode. The soybean treatment was responsible for an increase of two opportunistic c-p 1 and 2 bacterial-feeders, Panagrolaimidae and Drilocephalobus, but also one fungal-feeding taxon (Aphelenchus), a c-p 2 opportunistic nematode. The nematode community presents different patterns depending on the resources available in the soil $[36,37]$. After a fresh organic matter input in the soil, usually bacterial-feeding c-p 1 opportunistic nematodes like Rhabditidae develop first and are progressively replaced by fungal-feeding c-p 2 opportunistic nematodes. The higher density of Rhabditidae with residues in our experiment demonstrates both that the $\mathrm{OM}$ was highly processed by the bacteria, whereas the development of fungal-feeding c-p 2 nematodes like Aphelenchus populations showed that the conditions were favourable for the development of fungi $[3,31]$.

The density of fungal-feeders with rice residues was highly overestimated as in a replicate; there was a unexplained proliferation of Aphelenchoididae. Taking this into account, there was a trend of higher abundance of fungalfeeding nematodes with soybean than with rice (1541 versus 2084 individuals $\mathrm{kg}^{-1}$ dry soil, resp.). Actually, in 
this experiment, there were more twigs in the soybean treatment than in the rice treatment, thus explaining the development of fungi which are able to digest complex compounds like lignin $[31,37,38]$. When correcting the value of Aphelenchoididae in the treatment "mulch residue", omitting the outlier replicate, we found that fungal-feeding nematodes (Ditylenchus and Tylencholaimoidea) were significantly more abundant with buried residues than with mulched residues.

\section{Conclusion}

Our results showed that the earthworm $P$. corethrurus had a positive effect on total nematode densities mainly by increasing the density of dominant bacterial-feeding (Acrobeloides) and fungal-feeding (Aphelenchus) nematodes. The structure of the nematode community indicated that the decomposition of soybean residues was more fungal-based than that of the rice residues. Changes in the composition of the nematode fauna were greater when organic matter was buried in the soil than when it was left on the surface. Buried residues were responsible for the development of bacterialfeeder nematode populations, reflecting a stimulation of the bacterial compartment.

\section{Acknowledgment}

This study was conducted in the project Nemageco-Icones 0575C0042 funded by the French Environment and Energy Development Agency (ADEME).

\section{References}

[1] P. Lavelle and A. Spain, Soil Ecology, Kluwer Academic Publishers, Dordrecht, The Netherlands, 2001.

[2] H. Ferris, T. Bongers, and R. G. M. de Goede, "A framework for soil food web diagnostics: extension of the nematode faunal analysis concept," Applied Soil Ecology, vol. 18, no. 1, pp. 1329, 2001.

[3] T. Bongers and H. Ferris, "Nematode community structure as a bioindicator in environmental monitoring," Trends in Ecology and Evolution, vol. 14, no. 6, pp. 224-228, 1999.

[4] K. Ritz and D. L. Trudgill, "Utility of nematode community analysis as an integrated measure of the functional state of soils: perspectives and challenges: discussion paper," Plant and Soil, vol. 212, no. 1, pp. 1-11, 1999.

[5] T. Bongers and M. Bongers, "Functional diversity of nematodes," Applied Soil Ecology, vol. 10, no. 3, pp. 239-251, 1998.

[6] D. W. Freckman and E. P. Caswell, "The ecology of nematodes in agroecosystems," Annual Review of Phytopathology, vol. 23, pp. 275-296, 1985.

[7] G. W. Yeates and T. Bongers, "Nematode diversity in agroecosystems," Agriculture, Ecosystems and Environment, vol. 74, no. 1-3, pp. 113-135, 1999.

[8] T. Desjardins, F. Charpentier, B. Pashanasi, A. Pando-Bahuon, P. Lavelle, and A. Mariotti, "Effects of earthworm inoculation on soil organic matter dynamics of a cultivated ultisol," Pedobiologia, vol. 47, no. 5-6, pp. 835-841, 2003.

[9] C. Villenave, F. Charpentier, P. Lavelle, et al., "Effects of earthworms on soil organic matter and nutrient dynamics following earthworm inoculation in field experimental situations," in Earthworm Management in Tropical Agroecosystems, P. Lavelle, L. Brussaard, and P. Hendrix, Eds., pp. 173-197, Cabi, New York, NY, USA, 1999.

[10] M. Aira, F. Monroy, and J. Domínguez, "Effects of two species of earthworms (Allolobophora spp.) on soil systems: a microfaunal and biochemical analysis," Pedobiologia, vol. 47, no. 5-6, pp. 877-881, 2003.

[11] M. Aira, F. Monroy, J. Domínguez, and S. Mato, "How earthworm density affects microbial biomas and activity in pig manure," European Journal of Soil Biology, vol. 38, no. 1, pp. 710, 2002.

[12] R. Hyvönen, S. Andersson, M. Clarholm, and T. Persson, "Effects of lumbricids and enchytraeids on nematodes in limed and unlimed coniferous mor humus," Biology and Fertility of Soils, vol. 17, no. 3, pp. 201-205, 1994.

[13] K. Ilieva-Makulec and G. Makulec, "Effect of the earthworm Lumbricus rubellus on the nematode community in a peat meadow soil," European Journal of Soil Biology, vol. 38, no. 1, pp. 59-62, 2002.

[14] A. V. Tiunov, M. Bonkowski, M. Bonkowski, J. A. Tiunov, and S. Scheu, "Microflora, protozoa and nematoda in Lumbricus terrestris burrow walls: a laboratory experiment," Pedobiologia, vol. 45, no. 1, pp. 46-60, 2001.

[15] T. M. Razafimbelo, "Stockage et protection du carbone dans un sol ferrallitique sous systèmes en semis direct avec couverture végétale des hautes terres malgaches," Montpellier, 2005.

[16] S. Coq, B. G. Barthès, R. Oliver, B. Rabary, and E. Blanchart, "Earthworm activity affects soil aggregation and organic matter dynamics according to the quality and localization of crop residues-an experimental study (Madagascar)," Soil Biology and Biochemistry, vol. 39, no. 8, pp. 2119-2128, 2007.

[17] G. D. Bending, M. K. Turner, and J. E. Jones, "Interactions between crop residue and soil organic matter quality and the functional diversity of soil microbial communities," Soil Biology and Biochemistry, vol. 34, no. 8, pp. 1073-1082, 2002.

[18] C. Villenave, T. Bongers, K. Ekschmitt, P. Fernandes, and R. Oliver, "Changes in nematode communities after manuring in millet fields in Senegal," Nematology, vol. 5, no. 3, pp. 351-358, 2003.

[19] C. Villenave, K. Ekschmitt, S. Nazaret, and T. Bongers, "Interactions between nematodes and microbial communities in a tropical soil following manipulation of the soil food web," Soil Biology \& Biochemistry, vol. 36, no. 12, pp. 2033-2043, 2004.

[20] D. W. Freckman, "Bacterivorous nematodes and organicmatter decomposition," Agriculture, Ecosystems and Environment, vol. 24, no. 1-3, pp. 195-217, 1988.

[21] R. Lenz and G. Eisenbeis, "The vertical distribution of decomposition activity and of litter-colonizing nematodes in soils under different tillage," Pedobiologia, vol. 42, no. 3, pp. 193-204, 1998.

[22] C. Fragoso, G. G. Brown, J. C. Patron, et al., "Agricultural intensification, soil biodiversity and agroecosystem function in the tropics: the role of earthworms," Applied Soil Ecology, vol. 6, no. 1, pp. 17-35, 1997.

[23] S. Abiven, S. Recous, V. Reyes, and R. Oliver, "Mineralisation of $\mathrm{C}$ and $\mathrm{N}$ from root, stem and leaf residues in soil and role of their biochemical quality," Biology and Fertility of Soils, vol. 42, no. 2, pp. 119-128, 2005.

[24] J. T. Gilmour, A. Mauromoustakos, P. M. Gale, and R. J. Norman, "Kinetics of crop residue decomposition: variability 
among crops and years," Soil Science Society of America Journal, vol. 62, no. 3, pp. 750-755, 1998.

[25] J. J. s'Jacobb and J. van Bezooijen, A Manual for Practical Work in Nematology, Department of Nematology, Agricultural University, Wageningen, The Netherlands, 1986.

[26] G. W. Yeates, T. Bongers, R. G. M. de Goede, D. W. Freckman, and S. S. Georgieva, "Feeding habits in soil nematode families and genera-an outline for soil ecologists," Journal of Nematology, vol. 25, no. 3, pp. 315-331, 1993.

[27] J. Domínguez, R. W. Parmelee, and C. A. Edwards, "Interactions between Eisenia andrei (Oligochaeta) and nematode populations during vermicomposting," Pedobiologia, vol. 47, no. 1, pp. 53-60, 2003.

[28] E. Blanchart, A. Albrecht, J. Alegre, et al., "Effects of earthworms on soil structure and physical properties," in Earthworm Management in Tropical Agroecosystems, P. Lavelle, L. Brussaard, and P. Hendrix, Eds., pp. 149-172, Cabi, New York, NY, USA, 1999.

[29] I. Barois and P. Lavelle, "Changes in respiration rate and some physicochemical properties of a tropical soil during transit through Pontoscolex corethrurus (glossoscolecidae, oligochaeta)," Soil Biology and Biochemistry, vol. 18, no. 5, pp. 539-541, 1986.

[30] Y. Araujo, F. J. Luizão, and E. Barros, "Effect of earthworm addition on soil nitrogen availability, microbial biomass and litter decomposition in mesocosms," Biology and Fertility of Soils, vol. 39, no. 3, pp. 146-152, 2004.

[31] H. Ferris and M. M. Matute, "Structural and functional succession in the nematode fauna of a soil food web," Applied Soil Ecology, vol. 23, no. 2, pp. 93-110, 2003.

[32] D. Djigal, A. Brauman, T. A. Diop, J. L. Chotte, and C. Villenave, "Influence of bacterial-feeding nematodes (Cephalobidae) on soil microbial communities during maize growth," Soil Biology and Biochemistry, vol. 36, no. 2, pp. 323-331, 2004.

[33] G. W. Yeates, "Nematodes as soil indicators: functional and biodiversity aspects," Biology and Fertility of Soils, vol. 37, no. 4, pp. 199-210, 2003.

[34] L. Wasilewska, "Participation of soil nematodes in grass litter decomposition under diverse biocenotic conditions of meadows," Ekologia Polska, vol. 40, pp. 75-100, 1992.

[35] C. J. Wright and D. C. Coleman, "Cross-site comparison of soil microbial biomass, soil nutrient status, and nematode trophic groups," Pedobiologia, vol. 44, no. 1, pp. 2-23, 2000.

[36] L. Bjørnlund and S. Christensen, "How does litter quality and site heterogeneity interact on decomposer food webs of a seminatural forest?" Soil Biology and Biochemistry, vol. 37, no. 2, pp. 203-213, 2005.

[37] M. J. Vreeken-Buijs and L. Brussaard, "Soil mesofauna dynamics, wheat residue decomposition and nitrogen mineralization in buried litterbags," Biology and Fertility of Soils, vol. 23, no. 4, pp. 374-381, 1996.

[38] D. L. Porazinska, L. W. Duncan, R. McSorley, and J. H. Graham, "Nematode communities as indicators of status and processes of a soil ecosystem influenced by agricultural management practices," Applied Soil Ecology, vol. 13, no. 1, pp. 69-86, 1999. 

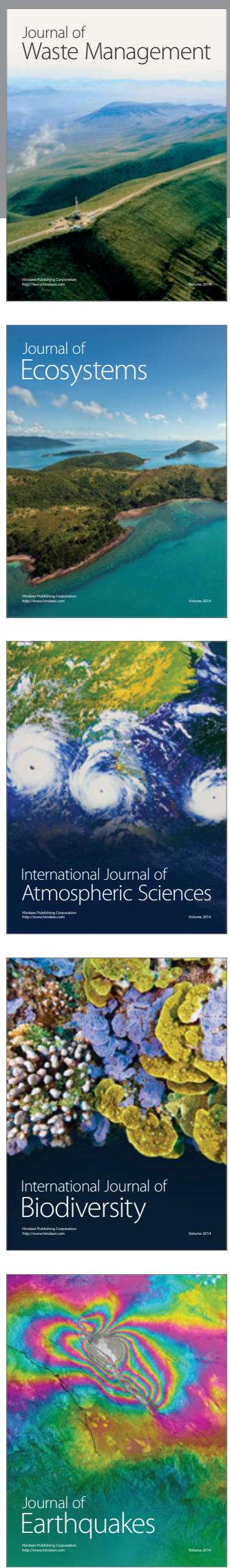
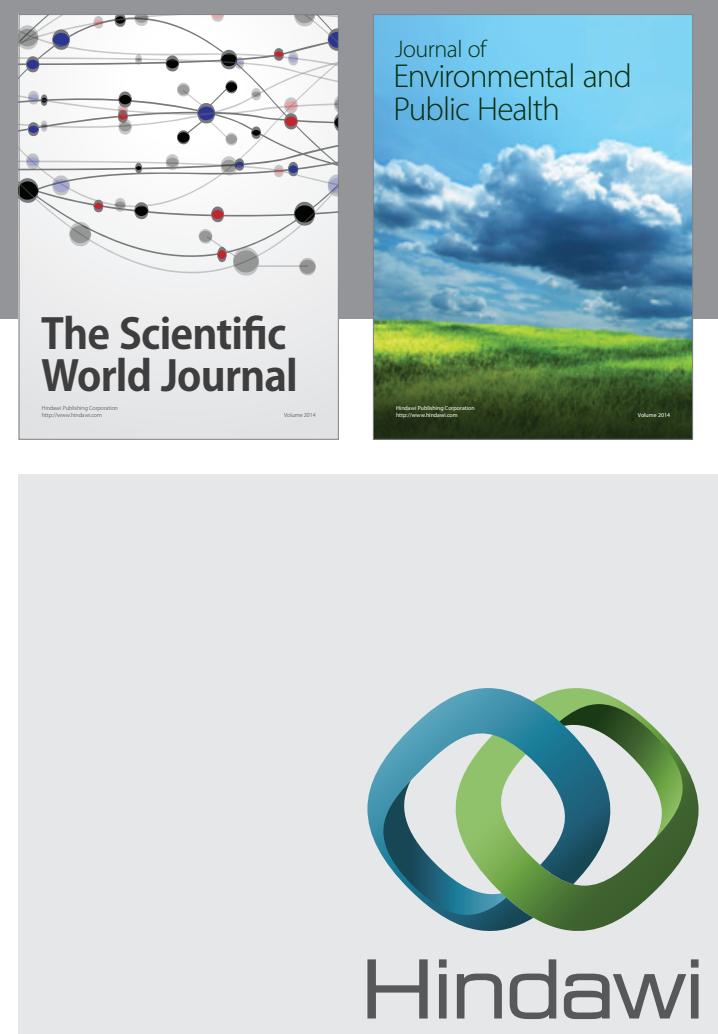

Submit your manuscripts at

http://www.hindawi.com
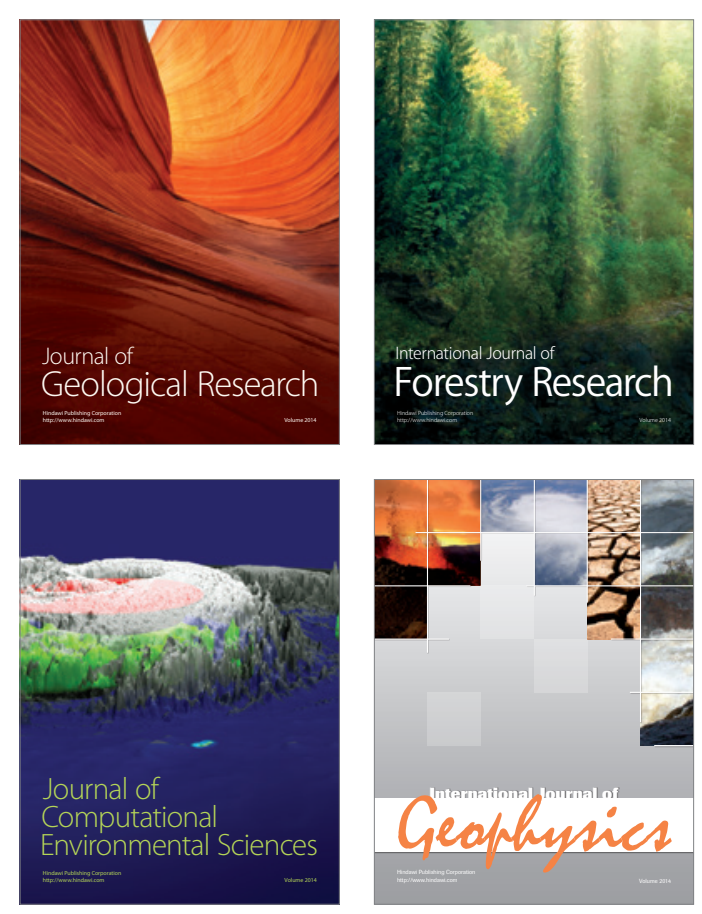
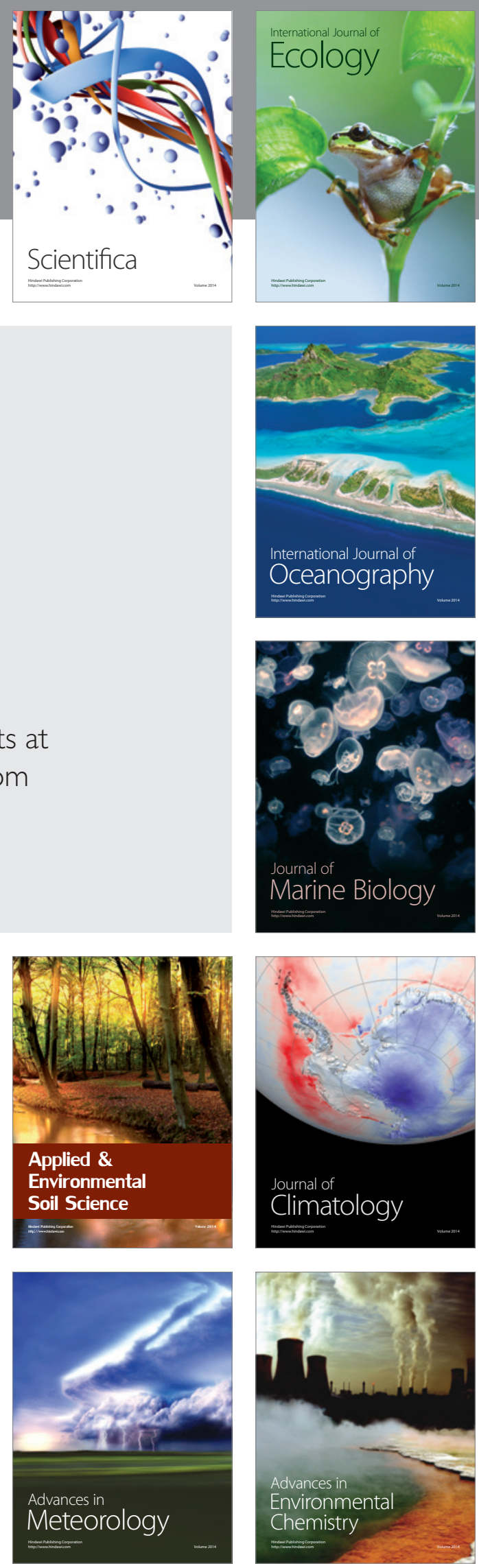